\title{
The Learning Effectiveness of Basic Throwing Movement Through Playing Approach
}

\author{
Mashud \\ Department of Sport Education and Health \\ Lambung Mangkurat University \\ Email: mashud@ulm.ac.id
}

\begin{abstract}
This research aimed to produce learning effectiveness of basic throwing movement. The study was conducted by involving research subjects' namely physical education teachers and first grade students of SDN Loktabat 7. This research used classroom action research method (action research) which has several phases of research steps including planning, action, observation and reflection. Data collected included qualitative, in the form of responses from observer/associate teacher in the form of criticism, suggestions, and comments both orally and written using interview techniques, discussion, documentation and questionnaires and quantitative data in the form scale of ordinal numbers. Data collected during the study is data about learning implementation and effectiveness of the learners. Before the action research was done, effectiveness of the students' learning outcomes in the form of concept understanding of basic throwing movement and throwing ability showed that there were 16 students $(45,71 \%)$ had finished the learning with standard grade individually. After the action research was conducted, the students who passed the study increased to $22(62.86 \%)$ in the first cycle, 26 students $(80 \%)$ in the second cycle, and 33 students $(94.29$ $\%$ ) in the third cycle. Before the action research was done, classical learning completeness of the students was $45.71 \%$. However, after the action research was conducted, it increased by $17.15 \%$ into $62.86 \%$ in cycle I. In the second cycle it increased by $11.43 \%$ into $74.29 \%$, while the third cycle, it increased by $20 \%$ into $94.29 \%$. While the study results of the learning implementation showed that the playing activity can be done well, it was proven by the high students' involvement and participation in learning, but the teacher should have more control of the movement preciousness done by the students, because it is feared the students focus only to do playing activities and they forget the right technique of basic throwing movement. Overall, the research phasing from the first until third cycle undergo the improving results, both effectiveness and implementation of basic throwing movement learning.
\end{abstract}

Keywords: learning effectiveness, basic throwing movement, playing approach

\section{INTRODUCTION}

Learning conception is an attempt to learn, so learning becomes easier for students [1]. Learning in this context is Physical Education, Sports and Health learning, where the learning uses physical movement media to educate the students, it means that through movement activities, the students are faced with learning experiences that try to guide them to achieve educational goals. Reference [2] stated that the aim of education in general is to deliver the success to the students in achieving their dreams and to set apart themselves from ignorance, so it can improve the quality of life.

Physical Education, Sports and Health learning to realize the full educational goals, must be accompanied by the involvement of various related components, especially for the teachers. The teachers become the center and the foundation of success in learning Physical Education, Sports and Health in schools. The teacher must take the time to design each lesson plan that will be carried out so that the learning objectives can be accommodated on each subject given to the students. The atmosphere and climate of learning must support the achievement of learning objectives, so the students will feel happy, comfortable, calm, be not threatened because of the fear of the teacher and the difficulties of learning material that is charged to the students. Besides that, learning must be designed to accommodate each of the unique characteristics of the students for the creation of active learning, so the students actively move, and do activities and there are no students who are silent/passive waiting for orders and turn from the teacher. The enjoyable and active condition of Physical Education, Sports and Health learning according to reference [3] is not enough, learning must be effective. Effective means to produce what students must master after the learning process takes place, it is because learning must have several objectives to be achieved.

Learning in elementary school emphasized on the mastery of basic movement skills of the learners, instilling values, attitudes and getting used to a healthy lifestyle reference [4]. The mastery of basic movement skills in elementary school includes basic movement of throwing patterns. Basic throwing movement is a fundamental skill to equip students in multilateral abilities perfectly [3]. In learning related to the subject of the basic movement of throwing in elementary schools, it often encounters problems that resulted in less optimal learning. Learning is often only centered on the teacher the teacher dominates the role in learning, and the active role of students is reduced. The teachers are less creative in presenting variations of learning so that the impact of boredom for the students. The complexity of this problem results in delay of the success of the students in achieving learning goals.

This phenomenon is closely related to Physical Education teachers as the spearhead in schools according to their level. The Physical Education teachers must be equipped with mastery of models, approaches, and strategies in learning to overcome various learning 
This classroom action research is designed in three cycles. Each cycle consists of (4) four stages, namely planning, implementation of action accompanied by (observation and field notes), reflection and analysis of subsequent planning improvements. The study is conducted on first grade students of SD Loktabat 7, Banjarbaru City, that the teacher played a role as the researcher as well as the subject of the study and the students as the model in the study [8].

\section{RESULTS AND DISCUSSION}

Based on the results of preliminary observations of basic throwing movement learning conducted at the first grade of students in SDN Loktabat 7 Banjarbaru City, it is known that 19 students of 35 students in the class had not yet finished the learning when doing basic throwing movement. The students who had finished the learning were students who could perform well and correctly the basic motion movements of throwing in accordance with the basic throwing movement indicators, namely: 1) Initial attitude, the position of the hand holding the turbo (javelin replacement). 2) Initial step position runs bringing the turbo. 3) The body swerves back in preparing for throwing. 4) Preparatory throwing movements is from the head. 5) Continuing movement is to maintain balance. 6) The result of turbo throw is curved to form the direction of a parabola.

Data from the initial observation result of the basic throwing movement learning can be seen in Table 1 . Based on the data table of the initial observation of the basic throwing movement above, there are 16 students who have finished the learning and 19 students who have not yet finished the learning individually. First grade is said to have not passed the learning because the percentage of classical learning completeness learning in first grade is $16 / 35 \times 100 \%=45.71 \%$.

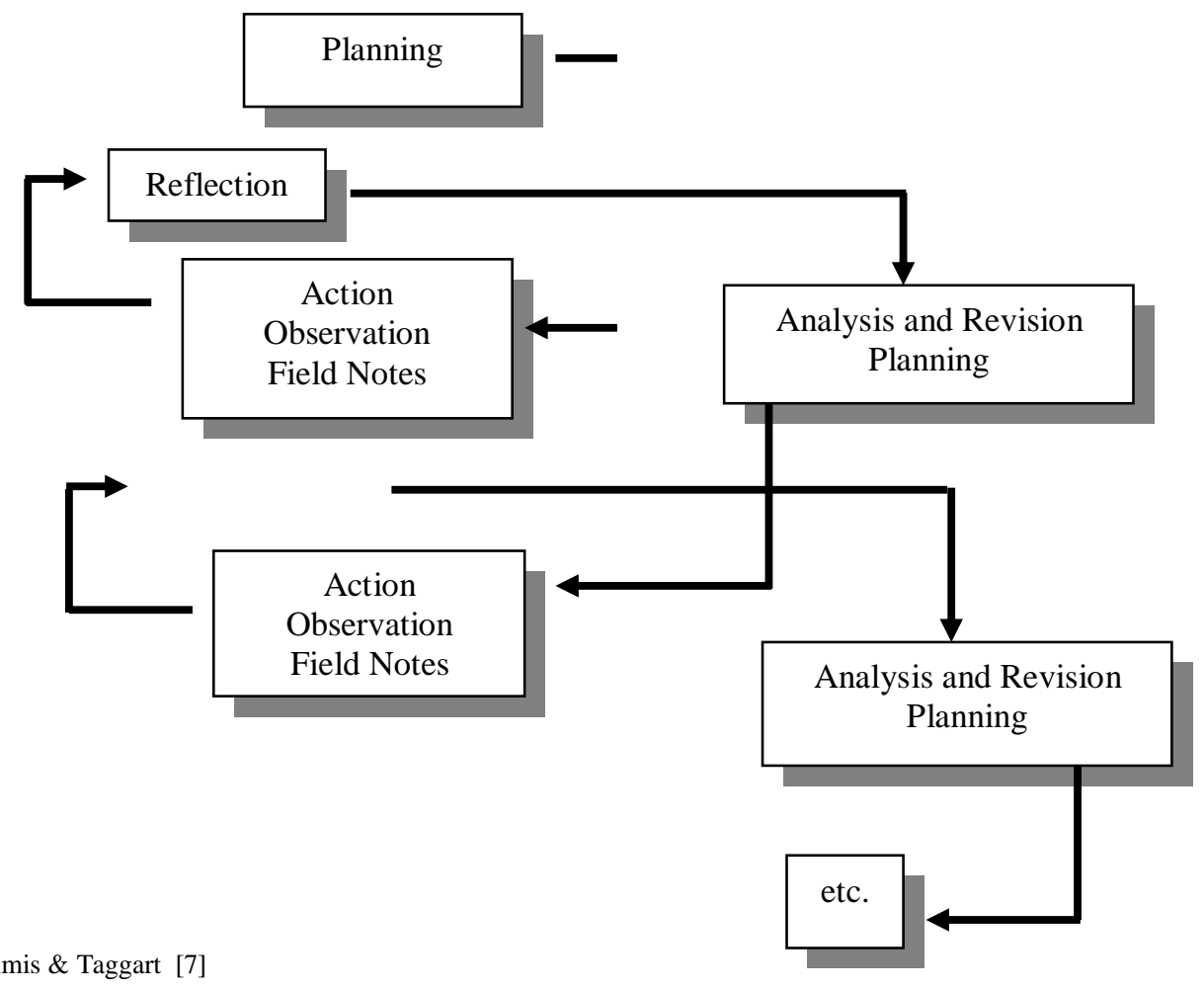

Fig. 1. The CAR model of Kemmis \& Taggart [7] 
throwing using a light ball, and the size of the ball is

TABLE I. RESULTS OF INITIAL OBSERVATION OF BASIC THROWING MOVEMENT

\begin{tabular}{|c|c|c|}
\hline Learning Completeness & $\begin{array}{c}\text { Students } \\
(\mathbf{\Sigma})\end{array}$ & $\begin{array}{c}\text { Percentage } \\
(\boldsymbol{\%})\end{array}$ \\
\hline Have finished & 16 & 45.71 \\
\hline Have not yet finished & 19 & 54.39 \\
\hline Total & 35 & 100.00 \\
\hline
\end{tabular}

Based on the problem faced by the teacher above, it is needed an appropriate solution to solve the problem, so they are expected to improve the quality and learning outcomes. Considering that if it is not immediately corrected, it will hamper the learning process so that the initial learning objectives cannot be achieved properly.

\section{A. Cycle I Data Exposure}

\section{1) Planning}

Because of the problem above, the researcher collaborated/discussed with physical education teachers to look for alternative solutions to solve the problem as an effort to improve learning. In this collaboration/discussion, a plan of teaching and learning activities will be prepared which will be outlined in the lesson plan. As for the results of discussions with the physical education teacher, a physical education lesson plan is arranged with the basic movement of throwing material as the basic topic as follows:

- Preparing of sub-subject lesson plan of basic movement of throwing material for class I includes competency standard, basic competency, indicators and learning strategies.

- Introduction consists of active stretching, warming up by playing games (tufted ball catching game and throwing games with the aim to prepare students for core activities).

- Learning core includes basic movement of throwing exercise with the help of the teacher and using several learning aids such as cardboard, funnel, hoop, volleyball and basketball.

- Closing in the form of passive stretching in pairs.

2) Implementation/action

Basic throwing movement learning process activities for the first cycle were carried out on October 1, 2013 with the following activities:

\section{a) Pre-Activity}

The process of basic throwing movement learning was implemented in first hour of lesson which was 07:30 to 09:30. Learning activities began by lining up the students into 4 lines. After praying, the teacher checked the students' presence list and the students did active stretching. Then, it was proceeding with the game of throwing and catching the tufted ball, throwing and catching the volleyball and basketball, and continued with throwing games which aim to create happiness in the atmosphere of the class that the learners do not feel bored.

\section{b) While Activity}

This learning main stage, the teacher gave an example of basic movement of throwing. Furthermore, with the guidance of the teacher, each student performed basic movement of increased to a rather large and heavy ball. It aims to make the students will be accustomed in doing basic throwing motion. This exercise aims to train the position of foot, and body, arm swing, throwing position, and continued motion after throwing in order to get a balanced position and not fall.

Furthermore, with the direction of the teacher, each student made variations in the basic movement of throwing to the target that had been designed by the teacher. Target is made as mark so that the students do not feel bored and there are few challenges, so the students are motivated and stimulated to always do throwing until they forget how many times, they have made the basic movement of throwing. This exercise was carried out continuously and alternately, and the most important is that the teacher must always change the variation of targets and how to throw.

\section{c) Post Activity}

In this activity, the students did passive stretching in pairs and the teacher provided evaluation to the learners about basic movement of throwing learning material to get information/input to improve the learning process that will be carried out in cycle II.

\section{3) Observation}

In the first cycle learning process, observation was made by physical education teacher (observer) to the researcher who was none other than physical education teacher who was carrying out basic movement of throwing learning. The results of the observation are as follows:

Observations for the learners:

- Learners were still awkward in warming up.

- All students looked happy in the learning process.

- Most of the students were brave but there were still some who still hesitant when doing basic throwing movements.

- Circulation or movement of the students from one form of the game to the other games still required a long time to set up.

- Observation for Physical Education Teachers:

- In general, the systematic implementation of learning carried out by physical education teachers ran well.

- The teacher's voice when teaching was clear, so the students were easy to accept learning material.

- The teacher always corrected the mistakes of each student when performing basic throwing movements.

- The placement of the teacher's position in the learning process was very good which was behind the students so that it made easier for the students to accept the main of learning.

- The teacher always gave examples of material with demonstrations when implementing the learning.

- The teacher was still a bit confused to arrange and explain especially on the type of game that would be given to students.

- The teacher seemed eager to deliver the learning material 
the start of the run, the hand throwing position was parallel to the front foot, so there was no wide range of movement for the throw. 3) After throwing, the body position was not balanced.

From the weaknesses that occur during learning in the first cycle, then in the next cycle (cycle II) learning, the researcher planned learning to be emphasized on improving the technique of the students in doing basic throwing movements.

4) Field Notes

Field notes need to be made to record important things that are not recorded during the learning process through observation sheets of the activities of the students and teacher during learning. The results of the field notes obtained from the observer are as follows:

- Students were seen to not do repetition training activities when doing basic throwing movements.

- Variations in the basic throwing movement exercises need to be added.

- Class management needs to be improved.

5) Reflection

a) From the observer

- Basic throwing movements exercises are more varied.

- When the students performed game, they were still confused because they were given the first-time opportunity to throw.

- When making basic movements of throwing, the students looked less serious.

\section{b) From the students}

- Before the main material was taught to students, the students looked happy with the various games provided.

- The Students expressed happiness until they forget the time when doing basic throwing movements.

- Basic throwing movement exercise by placing various kinds of targets was very fun.

\section{B. Analysis of Cycle I}

From the results of learning conducted in the first cycle, the learning that had been done has advantages and disadvantages. The advantages of learning that had been done in the first cycle include the following: Learning was already fun for the students and With the loss of the students' fear, the students' self-confidence arose and basically, the students were no longer reluctant to practice basic throwing movements.

Meanwhile the lacks or weaknesses contained in learning in the first cycle include the following:

- Learning by playing is effective for increasing the participation of students in learning, but because it was too fun to play, the teacher forgot to control the basic techniques of correct throwing.

- There were still many wrong basic movements of throwing done by students such as; 1) Throwing technique, hands were too sideways, so the direction of the throw was not parabolic. 2) When leaning after

\section{Cycle II Data Exposure}

In the first cycle study, there were still lacks which were mistakes in the basic movement of throwing were still done by learners. The learners still seemed awkward when doing the learning, lack of classroom management, and delivery of basic throwing movement learning by the teacher was still less varied and little bit boring.

Because of those lacks, the researcher as a physical education teacher performed basic throwing motion learning in cycle II. In this second cycle, the teacher more emphasized on the active involvement of the students in learning that focuses on the basic throwing movement learning, especially on the position of the hands, pedestals, throwing preparations and further movements. The activities in the second cycle were as follows:

\section{1) Planning}

Based on the analysis in the first cycle, it was found problems or deficiencies in the learning of basic throwing movement. The shortcoming was the lack of variety in for the students when throwing was the position of the hand when they were about to throw, the position of the foothold and the throwing hand were in the same line in front and there was no further movement after throwing. With the above problems, the researcher conducted discussions with physical education teacher to find alternative solutions to problems. In the discussion, a basic throwing movement learning plan was arranged which would later be outlined in the lesson plan. The results of the discussion in preparing the learning plan with the basic throwing movement material were as follows:

- It was found problems experienced by the students in doing basic throwing movements.

- Preparation of the learning device in the form of lesson plan with the basic throwing movement as the materials for class I.

- The introduction consisted of active stretching and throwing games.

- The main of the learning included the practice of throwing in a passive position, throwing hands behind the back to prepare for throwing while the opposite leg with the throwing hands forward as the foothold, and followed by the body twisting backward. After the position is considered correct, the students throw the ball to the wall as hard as possible. This kind of exercise was repeated until the automation of the throwing movement can be seen in the students. Then this movement was combined with running and throwing which was the focus of observation that the throwing hand must be opposite in order to get a wide training and classroom management. Whereas the problem 
- Classroom management had begun to run well, the students had begun to understand the transition from one game to another game.

- The post activity was in the form of evaluation of basic throwing movement learning and passive stretching in pairs.

\section{2) Implementation}

The activities in the second cycle were carried out on October 8, 2013. The cycle II activities are as follows:

\section{a) Pre activity}

The basic throwing movement learning process was carried out at the first lesson hour, which was at 07.30-09.30. Learning activity began by lining up students into 4 lines. After that, the students were praying, and the students checked the presence list, and the students did active stretching. Then, it was proceeding with throwing games. Throwing Games aimed to create a happy classroom atmosphere, so that the students did not feel bored.

\section{b) While activity of learning}

At the main learning activity, it includes practice of throwing in a passive position, throwing hands behind the back to prepare for throwing while the opposite leg with the throwing hands forward as a pedestal, and followed by the body twisting backward. After the position was considered correct, the students threw the ball to the wall as hard as possible. This kind of exercise was repeated until the automation of the throwing movement can be seen in the students. Then, this movement was combined with running and throwing and what being the focus of observation was the throwing hand must be opposite in order to get a wide throwing space and maintain the balance of the body, so they will not fall.

Furthermore, the teacher guided the students to do basic throwing movements by giving examples. In this activity, the teacher gave several examples of correct movements and hoping that the students really understand the correct movements in doing basic throwing movements.

\section{c) Post activities}

In this final activity, the teacher evaluated by observing the basic movement of throwing made by the students. From the evaluation result, it was known that all students did the basic throwing movements correctly. It was followed by the students doing passive stretching in pairs and continued with short discussion with the students about learning that had just been done in order to obtain additional information that was useful to make the learning that would be done next (cycle III).

\section{3) Observation}

In the second cycle learning process, observations were made by the researcher and the physical education teacher who were carrying out basic throwing movement learning. The results of the observation are as follows:

Observations for the learners:

- Students had not felt awkward in running the warming up.

- All students looked happy in the learning process.

- Every student tried to correct mistakes in the learning process.
Observations for physical education teachers:

- In general, the systematic implementation of learning carried out by physical education teachers ran well.

- The teacher's voice when teaching was clear, so the students were easy to accept learning material.

- The teacher always corrected the mistakes of each student when doing basic throwing movements.

- The placement of the teacher's position in the learning process was very good that was behind the students, so that it made it easier for the students to accept the main of learning.

- The teacher always gave examples of material by doing demonstrations when implementing the learning.

- The teacher had begun to enjoy arranging and explaining each game that was given to students.

- The teacher had provided appropriate guidance to individual students for basic movement learning.

- The teacher had given an evaluation on the basic movement learning of throwing.

- The learning process undertaken by the physical Learning Implementation Plan/Lesson Plan.

4) Field Notes

The results of the field notes obtained from the observer are as follows:

- Students looked more excited trying to do basic throwing movements.

- Students looked brave/no longer awkward when doing basic throwing movements learning.

- There was still a shortage of techniques exhibited by students, especially in terms of throwing techniques.

- Class management was quite good, especially the movement of the students from one game to another game was orderly and quickly adjusted.

5) Reflection

The results of learning reflection in cycle II are as follows:

\section{a) From the observer}

- Mistakes made by the students should be corrected immediately by giving examples of correct movements.

- It should be given motivation and improvement of movements of the students who were still not right in the throw.

- The expected learning objectives had been achieved

b) From the students education teacher was in accordance with the 
- Basic throwing movement exercises with a variety of variations and goals made the learners excited and happy.

- The game before stepping on the main material was very fun so that it raised the enthusiasm of the students in accepting the main material.

\section{Cycle II Analysis}

In cycle II, the fundamental mistakes in making basic movements of throwing were still made by the students. In addition, based on the results of evaluation of the basic throwing movement learning, there were 25 students who were correct in doing the movement.

From the results of learning carried out in cycle II, the learning that had been done has advantages and disadvantages. The advantages of learning that had been done in cycle II include the following:

- The active involvement of students in learning had reached $90 \%$.

- The students who were wrong in doing the basic throwing movement decreased in number (4 students) because physical education teacher had emphasized learning on the deficiencies or mistakes that occurred in previous learning.

- The basic throwing movement was done correctly by most of the students (26 students) although they needed further improvement.

Meanwhile the lacks or the weaknesses contained in learning of the second cycle include the following:

- a. The basic mistake was when the students started dropping the foot and throwing hand were not correct (throwing hand and foot were both in front), so that they could not make further movements properly and have an impact of the imperfect throwing.

- b. The results of the learning evaluation of basic movement throwing still stated at $74.29 \%$ of the students who were correct in making basic movement in throwing.

From the weaknesses that occurred when learning in cycle II, in the next cycle (cycle III) the researcher planned the learning activities to be emphasized on the improvement of the students' mistakes in cycle II.

\section{E. Cycle III Data Exposure}

In this cycle III, the teacher was no longer correcting the activeness of the students, the students had begun to adapt to the variations of learning and management designed by the teacher but the teacher rather emphasized the fundamental mistakes of basic throwing technique, which is the throwing hand must be parallel to the foothold and is opposite to the supporting foot. The activities in cycle III are as follows:

\section{1) Planning}

Based on the analysis in the second cycle, it was found there were problems or deficiencies in learning the basic movement of throwing in the second cycle. The shortcomings were more focused on the students, which when doing basic movements of the throwing, the students still made mistakes about the position of the throwing hand which was not parallel to the supporting foot. So that the movement space was narrow, and it was difficult to make further movements.

Due to above problem, the researcher and physical education teacher conducted discussions to find alternative solutions to the problem. In the discussion, a basic throwing movement learning plan was arranged which would later be outlined in the lesson plan. The results of the discussion in preparing the lesson plan are as follows:

- Preparation of learning device in the form of lesson plan.

- The introduction consisted of active stretching and ball throwing and catching game and throwing games.

- The main of this learning involved training by imagining that the throwing hand must be aligned with the foothold (right throwing hand, right foothold) and another foot as a supporting to carry out further movements so that it is balanced and does not fall.

- This post activity was in the form of evaluating the basic movement of throwing and passive stretching in pairs.

\section{2) Implementation}

The activities in cycle III were carried out on October 22, 2013. The cycle III activities are as follows:

\section{a) Initial activity}

The basic throwing movement learning process in this cycle was carried out at the first lesson hour, which was at 07.30-09.30. The activity began by the teacher leading the praying followed by the students doing active stretching from head to toe. It was then followed by games and throwing games. Those aimed to prepare the conditions of students to be ready to accept the main learning material.

\section{b) While activity of learning}

With the guidance from the teacher, the students lined up according to the group. The learners paid attention to the movement exemplified by the teacher and imitated it slowly. This exercise aimed to make the students able to place the throwing hand and foot position. This exercise was also done by the students repeatedly. After that, it was followed by the students doing the movement with the beginning of the walk, while they were still focusing on the position of the throwing hand parallel to the foothold. Thus, the activities were conducted by walking to get the right movement and added by running and staying focused on the position of the throwing hand and foothold stay parallel. Furthermore, the teacher observed the movements carried out by all students in turn. After all was considered able to practice well, the teacher replaced the ball with a turbo. At the final stage of this learning, the students were given time to keep repeating the movement until the movement became automatic.

\section{c) Post activity}

In this final activity, the teacher evaluated by observing the basic movement of throwing done by the students. From the evaluation results, it was known that almost all students 
correct in doing basic throwing movements. Thus, the basic throwing movement learning had been completed.

followed by the students doing passive stretching in pairs.

\section{3) Observation}

In the learning process, the observations were made by the researcher and physical education teacher who were carrying out the learning. The results of the observation are as follows:

Observations for learners:

- Learners already seemed familiar implementing the learning applied by the teacher.

- The students were serious and willingness in the learning process.

- The mistake in cycle II had begun to decrease, especially in the basic throwing movement technique.

- Management class when learning was already running well.

Observation for Physical Education Teacher:

- In general, the systematic implementation of learning carried out by physical education teachers ran well.

- The teacher had been able to focus on correcting the students' mistakes, especially on the basic techniques of throwing movement.

- Control of the students who were still unable to practice basic movement was more effective because the number of the students who had not been able to perform well the material decreased a little and all the students had adapted to the teacher learning method.

4) Field Notes

The results of the field notes obtained from the observer are as follows:

- The playing approach had been able to foster the active role of the students in learning.

- The students were able to do basic throwing movement properly and correctly.

\section{5) Reflection}

\section{a) From the observer}

The fundamental mistake made by the students which was placing the position of the throwing foot and the position of foothold which was not parallel was not appeared anymore. The expected goals of learning had been reached.

\section{b) From the students}

Basic throwing movement exercises with the playing approach made the learners more active and it fostered the atmosphere of fun or happiness in the learning, especially basic throwing movement learning. The game before going on the main material was very fun, so that it raised the enthusiasm of the students in accepting the main material.

\section{F. Cycle III Analysis}

Learning in the cycle III had been successful. This can be seen from the results of observations and evaluations of the study which stated that the first-class students of SDN Loktabat 7, Banjarbaru City, which were 33 students were all

\section{G. Evaluation of Basic Throwing Movement in Cycle I}

After learning activities were completed, the next activity was the provision of assessment tests. This assessment test aimed to measure the ability of the students after learning. The results of the basic throwing movement assessment in cycle I can be seen in Table 2 .

TABLE II. EVALUATION OF BASIC THROWING MOVEMENT IN CYCLE

\begin{tabular}{|c|l|l|}
\hline Learning Completeness & Learners $(\Sigma)$ & Percentage (\%) \\
\hline Have finished & 22 & 62.86 \\
\hline Have not yet finished & 13 & 37,14 \\
\hline Total & 35 & 100.00 \\
\hline
\end{tabular}

Based on the table of basic throwing movement assessment results above, in the first cycle, there were 22 students $(62.86 \%)$ who had finished learning and 13 students (37.14\%) who had not yet finished learning individually. The percentage of classical learning completeness in the first cycle was $22 / 35 \times 100 \%=62.86 \%$.

\section{H. Evaluation of Basic Throwing Movement in Cycle II}

As in the first cycle, the assessment test was also carried out at the end of the lesson. It was expected that in this second cycle there would be an increase in both individual assessments and classical assessments. The results of the basic throwing movement assessment test can be seen in Table 3.

TABLE III. EVALUATION OF BASIC THROWING IN CYCLE II

\begin{tabular}{|l|l|l|}
\hline \multicolumn{1}{|c|}{ Learning Completeness } & \multicolumn{1}{|c|}{ Learners $(\Sigma)$} & Percentage (\%) \\
\hline Have finished & 28 & 80 \\
\hline Have not yet finished & 9 & 20 \\
\hline Total & 35 & 100.00 \\
\hline
\end{tabular}

Based on the table of basic throwing movement assessment results above, in the cycle II, there were 26 students $(74.29 \%)$ who had finished learning and 9 students $(25.71 \%)$ who had not yet finished learning individually. The percentage of classical learning completeness in the second cycle was $28 / 35 \times 100 \%=80 \%$.

\section{Evaluation of Basic Throwing Movement in Cycle III}

The results of the basic throwing movement assessment can be seen in Table 4 below:

TABle IV. Evaluation of Basic Throwing Movement In CyCle III

\begin{tabular}{|l|l|l|}
\hline \multicolumn{1}{|c|}{ Learning Completeness } & Learners $\left(\sum\right)$ & Percentage (\%) \\
\hline Have finished & 33 & 94.29 \\
\hline Have not yet finished & 2 & 5.71 \\
\hline Total & 35 & 100.00 \\
\hline
\end{tabular}

Based on the table of basic throwing movement assessment results above, from the completeness of individual learning there were 33 students who had finished learning and 2 students who had not yet finished learning. 
objectives at the beginning of learning are difficult to achieve.

Increase in the number of students who have finished learning individually and classical learning completeness when performing basic throwing movements from before and after the implementation of CAR indicates that the playing approach and learning variations which were designed and programmed by the teacher in the physical education learning systematics which consists of introduction, main and post succeed in improving the students' learning outcomes. Based on the comparison of the results of the basic throwing movements before and after the CAR showed significant increase after an improvement in learning variation.

\section{CONCLUSION}

The playing approach given by the teacher can improve the effectiveness of learning and learning outcomes of the basic throwing movement for the first-grade students of SDN Loktabat 7, Banjarbaru City.

Related to the conclusion on the results of classroom action research implementation in SDN Loktabat 7 Banjarbaru City for class I in the basic throwing movement learning process, there are several suggestions, namely:

- Physical education teacher is expected to be more creative and varied again in bringing up the playing approach in learning.

- This class action research should be developed in other learning as an effort to improve the quality of physical education learning.

- Physical education teacher is expected to create a variety of media and learning models.

\section{REFERENCES} $11.43 \%$ into $74.29 \%$ and while in the cycle III, the students' classical learning completeness increased by $20 \%$ into $94.29 \%$.

One of the successes in learning is ability of teacher to plan and implement the learning. Effective learning activities cannot arise by themselves, but the teacher must create learning that allows the students to achieve the goals set optimally. The teacher is required to be able to create learning situations/conditions that enable the occurrence of the teaching and learning process to the students.

Variations in learning that are designed and programmed by the teacher are effort to improve the quality and learning outcomes. Without the variety of learning that is designed and programmed by the teacher in physical education learning systematics which consists of introduction/pre, main/while and post activities, the expected learning
[1] D. Dwiyogo, and Wasis, Rancangan Pembelajaran Pendidikan Jasmani Olahraga, Malang: Wineka Media, 2002.

[2] A. Abdul Kadir, Pengantar Asas Asas Landasan Pendidikan Jasmani, Olahraga dan Rekreasi, Jakarta: P2LPTK Dtjen Dikti, 1989.

[3] D. Heryana, \& G. Verianti, Pendidikan Jasmani Olahraga dan Kesehatan, Jakarta: 2010.

[4] M. Muhadi, Pendidikan Jasmani dan Kesehatan, Jakarta: Depdikbud, 1993.

[5] S. Sutoto, Pendidikan permainan anak dan aktivitas ritmik, Jakarta: Depdikbud, 1991.

[6] T. Subroto, Teori Bermain, Bandung: Universitas Pendidikan Indonesia, 2009.

[7] D. Dasna, W. Wayan and A. Fatchan, Penelitian Tindakan Kelas \& Penulisan Karya Ilmiah, Malang: Universitas Negeri Malang Panitia Sertifikasi Guru (PSG) rayon 15, 2009.

[8] H. Chotimah, “Tips Menjadi Guru Inspiratif”, 2008. 